\title{
WORKING CAPITAL IN ESTONIAN AGRICULTURAL COMPANIES: ANALYSIS BY SIZE
}

\author{
Maire Nurmet ${ }^{1}, \mathrm{PhD} /$ associated professor; Katrin Lemsalu ${ }^{2}, \mathrm{MSc} /$ lecturer and
}

Juri Lehtsaar ${ }^{3}, \mathrm{PhD} /$ senior lecturer

\section{1, 2, 3 Estonian University of Life Sciences}

\begin{abstract}
The paper examines the working capital indicators to find out the differences between larger and smaller Estonian agricultural companies. In the task of working capital management, a balance between profitability and liquidity is under investigation. A higher level of current assets ensures higher liquidity, but reduces the profitability. The share of inventories in current assets is relatively high in agricultural companies, and can lead to liquidity problems in adverse circumstances. Low levels of current assets can lead to business interruptions, as insufficient stocks lead to delays in the production process, which in turn is amplified in yields or other outputs. The number of employees is used to distinguish the size of the company. The results show that the smallest agricultural companies have higher liquidity and relatively larger share of highly liquid current assets. Larger agricultural companies maintain a higher level of inventory and have a longer inventory turnover period. Smaller companies have a slightly higher share of loans in current liabilities, so they have to maintain a larger financial buffer. The cash conversion cycle is longer for the smallest and the largest agricultural companies while medium-sized companies have a shorter cash conversion cycle. Smaller companies have the longest receivables turnover, showing that they enable longer payment periods for buyers or may have difficulties collecting receivables from the production sold. Having low market power and long receivables turnover, they have relatively higher need for working capital.
\end{abstract}

Key words: working capital management, agricultural companies, analysis by size.

JEL code: M41, L25, Q12

\section{Introduction}

The key issue in working capital management is to make trade-offs between profitability and liquidity. Working capital allocation and management has recently got more attention across and within industries (Banos-Caballero, S. et al., 2020; Chen, C., Kieschnick, R., 2018; Pirttila, M. et al., 2019; Jedrzejczak-Gas, J., 2017; Dhole, S. et al., 2019, Duong, P. et al., 2020).

Working capital is a measure of the liquidity of companies in the agricultural sector. The larger the number of the net balance between current assets and current liabilities, the more liquidity is available in the sector. This enables to indicate the amount of cash that agricultural companies have available to make purchases of inputs and repay their short-term liabilities. The easiest way to generate liquidity or working capital is to earn profits from agricultural production. Therefore, working capital tends to decline as profitability declines. As a result, maintaining a higher level of current assets ensures higher liquidity, but may reduce the financial performance of a company. Working capital policy can affect the efficiency of the company's operation, which impacts on the possibility of gaining profit and improving financial performance (Deloof, M., 2003). Financial performance is associated with managing working capital. Working capital management reduces the likelihood of future financial constraints, enables companies to free up cash and improve liquidity (Banos-Caballero, S. et al., 2010). This balance between performance and liquidity in agriculture is due to the specific nature of the sector (Piccoli, P. et al., 2020). The specific compromise-balancing between financial performance and liquidity in agricultural companies is caused by external factors, as well as farmer and farm-related factors, and farm characteristics.

The scarcity of working capital of dairy and crop farming companies is the result of financial problems in the Estonian agricultural sector for the last five years. The price of milk has fallen to its lowest in recent years and producers have to sell milk below the cost price. Buyers of raw milk do not adhere to the prices

maire.nurmet@emu.ee

katrin.lemsalu@emu.ee

3 jyri.lehtsaar@emu.ee 
specified in the contract and pay below the previously agreed level. Dairy farmers have one-year contracts with the dairy industry. The dairy industry is in a stronger position in this situation and dairy farmers need to adapt. They need to monitor their incomes closely. In order to save costs, many agricultural companies have given up buying the necessary fertilizer and renewing their seeds and thus maintain fewer inventories. The low stock of dairy cattle feed would reduce milk production in the next period (Lukjanov, S., 2020). Recently, many crop growers had a problem with a lack of working capital when crop production was low due to drought damage. Politicians consider that working capital loans would help farmers survive difficult times (Uhise põllumajanduspoliitika... 2019). Aware of the situation, and withstanding a difficult financial situation, agricultural firms must have a conservative working capital policy.

The level of working capital is an indication of the strength of the company's strategic position. Working capital is the net balance of operating costs and sources of funds. The level of working capital reflects the balance of power between the company and its customers and suppliers. In countries where financial and economic development is higher and the legislation is more strongly enforced, greater value is attached to working capital management (Banos-Caballero, S. et al., 2020). In this field a number of studies (Banos-Caballero, S. et al., 2010; Chen, C., Kieschnick, R., 2018; Piccoli, P. et al., 2020) using different methods have recently been conducted, producing various results. Several studies provided an understanding of what significantly influences corporate working capital management. A more aggressive working capital policy was observed among companies that had better growth opportunities and companies with higher leverage, investment in fixed assets and return on assets. (Banos-Caballero, S. et al., 2010). Chen, C., Kieschnick, R. (2018), providing an understanding of influencing factors of corporate working capital management found that changes in the availability of bank credit significantly influenced a number of aspects of a firm's working capital policies. These effects differed across firms that are more or less dependent on bank financing.

In the field of agriculture, Piccoli, P. et al., (2020) have explained the lower capacity of agricultural cooperatives of providing resources from their operations. They found that the expansion of net working capital caused by the growth of revenues was mostly funded by short-term debt in agricultural cooperatives. They also found that more than half of firms displayed a current capital structure that could be considered risky in terms of indebtedness, and that the majority of firms exhibited non-sustainable growth in the period. The size of a company plays role in working capital management (Bridging the Gap, 2015). Larger companies tend to be better at managing their working capital. Smaller businesses often have less sophisticated working processes, systems and functional expertise, whilst they have a greater need for effective cash management.

In this analysis the working capital indicators in Estonian agricultural companies are examined in order to find out the differences between larger and smaller enterprises. The aim of the paper is to explore the differences of working capital between larger and smaller agricultural companies in Estonia.

The sample of the analysis includes Estonian agricultural companies engaging crop and livestock production and integral ancillary activities and agricultural service activities. The data were obtained from the database of Statistics Estonia (ESA). From the database, the code A01 for crop and animal production, hunting and related service activities was chosen as the activity code. In the process of data collection, the balance sheets and income statements of companies in the original sample were downloaded in Excel form. The year-end basis data was used to calculate liquidity ratios (current ratio, quick ratio, cash ratio) and other working capital performance indicators. The measure of working capital requirements relative to the size of the company is Net working capital (NWC). The measure of efficiency is Inventories turnover (IT). The measure of inventories relative to assets is Inventories to current assets (ICA). Generally, the lower 
the ICA, the better the financial performance. The indicator of financial performance is measured by profits as a proportion of a company's owners' equity: Return on equity (ROE). The number of employees is used to distinguish the size of the company.

This study contributes to the understanding of working capital needs in the farm sector, using annual accounting data from financial statements of agricultural companies. The novelty of this study is that it uses the accounting data from financial statements of companies instead of the FADN data. It is based on agricultural companies' financial indicators of the beginning and end of the year.

\section{Research results and discussion}

\section{The sample of the study}

The value of the total output of the agriculture at basic prices including product subsidies was $€ 1036$ million in 2019. Of the total production value, the value of total crop production accounted for $48 \%$, the value of total livestock production for $41 \%$ and integral ancillary activities and agricultural service activities for $11 \%$. (ESA; Pollumajanduse ... 2020)

From the database, the code A01 for crop and animal production, hunting and related service activities was chosen as the activity code. The number of companies resulting from this search is shown in Table 1.

Table 1

Number of companies: Crop and animal production, hunting and related
service activities
\begin{tabular}{|l|l|l|l|l|l|l|l|l|l|l|l|}
\hline & $\mathbf{2 0 0 8}$ & $\mathbf{2 0 0 9}$ & $\mathbf{2 0 1 0}$ & $\mathbf{2 0 1 1}$ & $\mathbf{2 0 1 2}$ & $\mathbf{2 0 1 3}$ & $\mathbf{2 0 1 4}$ & $\mathbf{2 0 1 5}$ & $\mathbf{2 0 1 6}$ & $\mathbf{2 0 1 7}$ & $\mathbf{2 0 1 8}$ \\
\hline $\begin{array}{l}\text { Number of } \\
\text { companies } \\
\text { Crop and } \\
\text { animal } \\
\text { production, } \\
\text { hunting } \\
\text { and related } \\
\text { service } \\
\text { activities }\end{array}$ & 1060 & 1116 & 1153 & 1288 & 1451 & 1673 & 1877 & 2206 & 2398 & 2618 & 2782 \\
\hline $\begin{array}{l}\text { of that 1-9 } \\
\text { employees }\end{array}$ & 789 & 860 & 914 & 1066 & 1236 & 1458 & 1678 & 1985 & 2186 & 2418 & 2579 \\
\hline $\begin{array}{l}\ldots .10-49 \\
\text { employees }\end{array}$ & 233 & 218 & 205 & 186 & 185 & 182 & 165 & 187 & 182 & 175 & 186 \\
\hline $\begin{array}{l}\ldots .50-99 \\
\text { employees }\end{array}$ & 27 & 27 & 25 & 27 & 20 & 23 & 25 & 27 & 24 & 20 & 17 \\
\hline
\end{tabular}

\section{Source: ESA}

The number of companies in the database has increased during the analysed period. The decrease in the number of companies with a large number of employees is certainly caused by the increase in labour productivity. In some cases, larger companies have been split into smaller ones in order to take full advantage of the support schemes.

\section{Estonian agricultural companies' liquidity}

Working capital is the net balance of current assets and short term liabilities. Working capital management is about making trade-offs between profitability and liquidity. Maintaining a higher level of current assets ensures higher liquidity. Figure 1 shows the liquidity indicators of Estonian agricultural companies on the basis of all size groups. Liquidity ratios are calculated at three levels - current ratio (current assets to current liabilities), quick ratio (current assets minus inventories to current liabilities), 
cash ratio (cash to current liabilities). The liquidity of agricultural companies is sufficient, considering the low season in agriculture at the beginning and the end of the year.

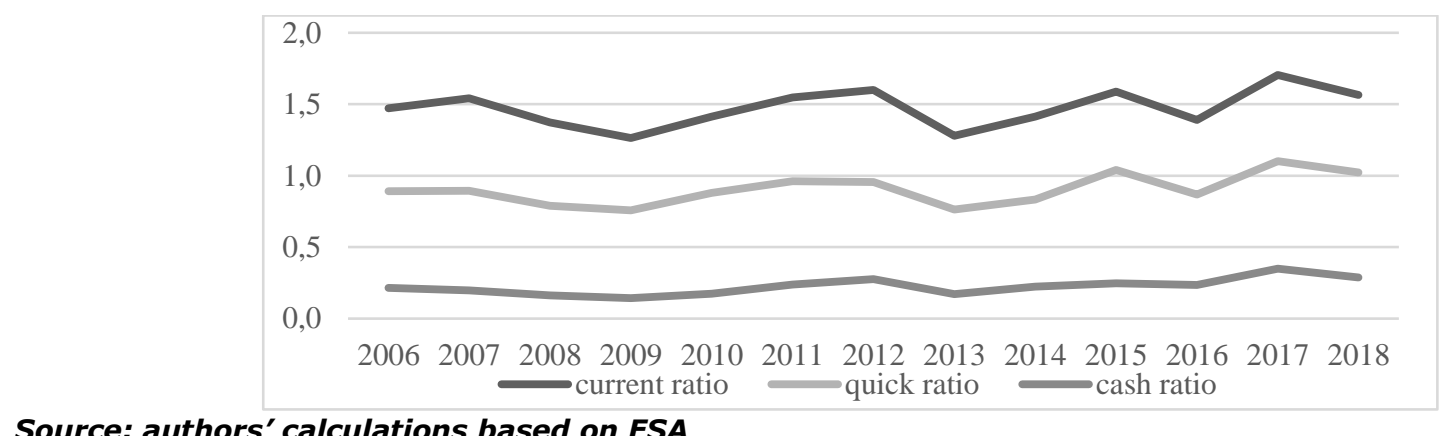

Source: authors' calculations based on ESA

Fig. 1. Liquidity ratios in agricultural companies: Crop and animal production, hunting and related service activities (2005-2018)

The share of inventories in current assets is relatively large in agriculture. One possibility of making trade-offs between profitability and liquidity is optimizing working capital by decreasing the share of stock in total assets. Maintaining a higher level of current assets ensures higher liquidity, but reduces the company's chances of making a profit. In the current situation the share of inventories in assets and the share of inventories in current assets have fallen. The profitability, measured as return on equity has a cyclical, but downward trend in 2005-2018 (Figure 2).

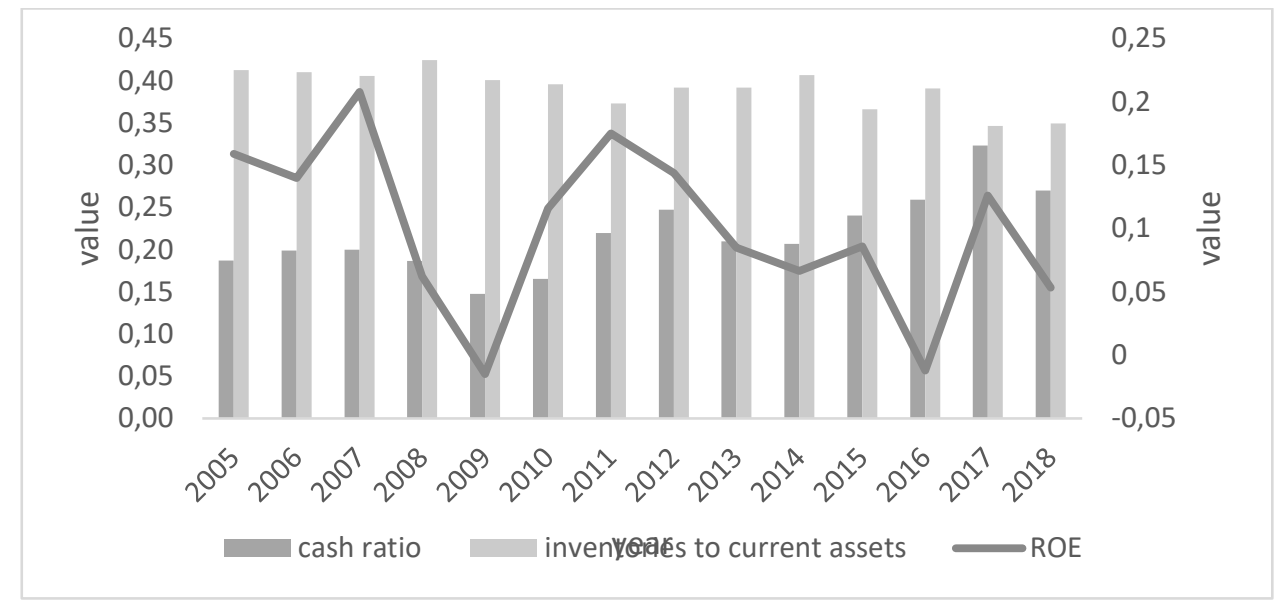

\section{Source: authors' calculations based on ESA}

Fig. 2. Liquidity and profitability in agricultural companies: Crop and animal production, hunting and related service activities (2005-2018)

The fact that inventories are maintained to a lesser extent has increased the liquidity. On the other hand, low levels of inventories in current assets can lead to business interruptions, as insufficient stocks lead to delays in the production process, which in turn are amplified in yields or other outputs. This may lead to lower liquidity, which increases the risk of insolvency.

\section{Working capital management in agricultural companies}

In crop production companies a relatively large share of the capital is invested in stocks. If the share of inventories in current assets is relatively high, it may lead to liquidity problems unfavourable circumstances. Maintaining optimal inventories generally increases the ability to make a profit. As a result, farms have a day-to-day focus on addressing the challenges of optimal inventory and working capital management. Currently, the efficiency improvement in use of stocks and a reduction in inventories has not increased companies' profitability (Figure 3). During the observable period the return on equity (ROE) has decreased, 
the share of inventories in assets has declined and agricultural companies' liquidity has increased. This situation indicates that it will result in the shortage of working capital, which has been due, among other things, to cost savings due to the low yields and low price of milk, which may jeopardize the sustainability of production.

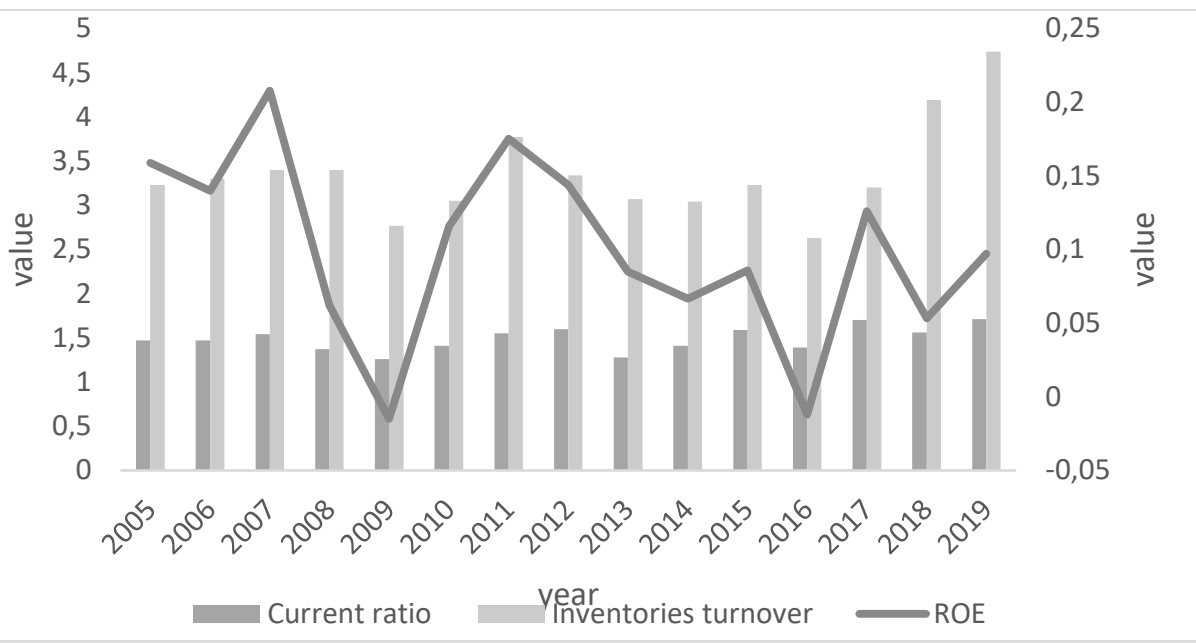

Source: authors' calculations based on ESA (EM001)

Fig. 3. The liquidity, efficiency and profitability in agricultural companies: Crop and animal production, hunting and related service activities (2005-2018)

In a situation where profitability temporarily decreases and the level of inventories falls, there may be a risk of insufficiency of current assets to purchase inputs and the production may fall due to insufficiency of current assets.

\section{Liquidity and profitability in agricultural companies by size}

The number of employees is used to distinguish the size of the company. The results show that the smallest agricultural companies with 1-9 employees have higher liquidity than medium- sized companies (Table 2).

Table 2

Liquidity ratios and profitability by the size of agricultural companies: Crop and animal production, hunting and related service activities (2005-2008)

\begin{tabular}{|c|c|c|c|c|c|c|c|}
\hline No & & $2005-2018$ & Total & $1 \ldots 9$ & $10 . .19$ & $20 . .49$ & 50...99 \\
\hline \multirow{3}{*}{1} & \multirow{3}{*}{ Current ratio } & Average & 1.45 & 1.53 & 1.36 & 1.35 & 1.54 \\
\hline & & Minimum & 1.04 & 1.21 & 1.13 & 1.12 & 1.04 \\
\hline & & Maximum & 1.94 & 1.94 & 1.69 & 1.47 & 1.82 \\
\hline \multirow{3}{*}{2} & \multirow{3}{*}{ Quick ratio } & Average & 0.86 & 1.04 & 0.87 & 0.73 & 0.72 \\
\hline & & Minimum & 0.46 & 0.82 & 0.75 & 0.60 & 0.46 \\
\hline & & Maximum & 1.38 & 1.38 & 1.11 & 0.82 & 1.01 \\
\hline \multirow{3}{*}{3} & \multirow{3}{*}{ Cash ratio } & Average & 0.22 & 0.37 & 0.22 & 0.15 & 0.15 \\
\hline & & Minimum & 0.06 & 0.22 & 0.15 & 0.10 & 0.06 \\
\hline & & Maximum & 0.54 & 0.54 & 0.41 & 0.18 & 0.34 \\
\hline \multirow{3}{*}{4} & \multirow{3}{*}{ ROE } & Average & 0.09 & 0.15 & 0.08 & 0.07 & 0.06 \\
\hline & & Minimum & -0.09 & 0.04 & 0.05 & -0.09 & -0.08 \\
\hline & & Maximum & 0.25 & 0.25 & 0.22 & 0.19 & 0.16 \\
\hline
\end{tabular}

Source: authors' calculations based on ESA, 2021 
The smallest agricultural companies have a relatively larger share of highly liquid current assets (cash and receivables and prepayments). However, large agricultural companies (50-99 employees) have relatively more stocks. Smaller companies have a slightly higher share of loans in current liabilities, so they have to maintain a larger financial buffer. The cash conversion cycle is longer for the smallest (1-9 employees) and the largest (50-99 employees) agricultural companies. Medium-sized companies (10-19 employees) have a shorter cash conversion cycle. Smaller companies have the longest receivables turnover, indicating that small companies allow buyers longer payment periods. Larger companies have a longer inventory turnover period, which is due to the fact that larger companies maintain a larger inventory.

Based on these results, it can be pointed out that smaller agricultural companies may find it more difficult to collect receivables from buyers for the production sold. Smaller companies have low market power and, in order to sell at all, they have to allow buyers longer payment periods. Therefore, they have to account for the relatively large volume of receivables and the relatively higher need for working capital. Thus, small agricultural companies have a more conservative working capital management policy. A more conservative working capital policy reduces the risks associated with the company's operations, which are usually higher for smaller companies.

A limiting factor for the analysis is that a better overview of the working capital management of agricultural holdings would be obtained if monthly data could be used. The analysis is based on the data of financial indicators of enterprises published by Statistics Estonia at the beginning and end of the year. For a farm, the activity of agricultural activities is low at the turn of the year, which is why the working capital indicators may be somewhat different during the season

\section{Conclusions, proposals, recommendations}

The analysis examined the working capital indicators in Estonian agricultural companies exploring the differences between larger and smaller companies.

Working capital management includes the question about the compromise between profitability and liquidity. Maintaining a higher level of current assets ensures higher liquidity, but reduces the company's chances of making a profit. Agricultural companies have a permanent focus on addressing the challenges of optimal inventory and working capital management. The results show that:

1) compared to large companies, the smallest agricultural companies have a relatively larger share of highly liquid current assets, less stocks in assets, and slightly higher share of loans in current liabilities;

2) small companies have the longest receivables turnover, indicating that small companies enable longer payment periods for buyers;

3) compared to medium-size companies, the money conversion cycle is longer for the smallest and the largest agricultural companies;

4) larger companies maintain a higher level of inventory, having longer inventory turnover period. The following recommendations can be made to agricultural companies for working capital management.

5) It is necessary to all companies to ensure that sufficient working capital is available in a situation where sales revenue and profitability temporarily fall. This enables to procure production inputs for the following years, and avoid a situation where the production will remain low due to insufficient inputs.

6) It is important for larger companies to ensure that sufficient current assets, particularly cash, is available during a temporary downturn.

7) It is recommended for small companies to find ways to extend the payment terms to accounts payable, which reduces the share of interest-bearing liabilities in the structure of short-term liabilities. 
8) Alternatives to finance working capital are needed in order to control the level of short-term liabilities. Financing working capital by providing additional financing from owners' equity is one option.

\section{Bibliography}

1. Banos-Caballero, S., García-Teruel, P.J., Martínez-Solano, P. (2020). Net Operating Working Capital and Firm Value: A Cross-country Analysis. BRQ Business Research Quarterly. Volume 23, Issue 3 https://doi.org/10.1177/2340944420941464.

2. Banos-Caballero, S., García-Teruel, P.J., Martínez-Solano, P. (2010). Working Capital Management in SMEs. Accounting \& Finance, Volume 50, No. 3, pp. 511-527.

3. Bridging the Gap. 2015 Annual Global Working Capital Survey. PWC. Retrieved: https://www.pwc.com/gx/en/business-recovery-restructuring-services/working-capital-management/workingcapital-survey/2015/assets/global-working-capital-survey-2015-report.pdf Access: 11.03.2021.

4. Chen, C., Kieschnick, R. (2018). Bank Credit and Corporate Working Capital Management. Journal of Corporate Finance, Volume 48(C), pp. 579-596.

5. Deloof, M., (2003). Does Working Capital Management Affect Profitability of Belgian Firms? Journal of Business Finance and Accounting, Volume 30(3-4), pp. 573-587.

6. Dhole, S., Mishra, S., Pal, A.M., (2019). Efficient Working Capital Management, Financial Constraints and Firm Value: A Text-based Analysis. Pacific-Basin Finance Journal, Volume 58: 101212.

7. Duong, P., Thao, P., Ha, H.T.C., (2020). The Impact of Trade Credit Investment on Manufacturing Firms' Profitability: Evidence from Vietnam. Acta Universitatis Agriculturae et Silviculturae Mendelianae Brunensis, Volume 68(4): 775-796.

8. Jedrzejczak-Gas, J. (2017). Net Working Capital Management Strategies in the Construction Enterprises Listed on the NewConnect Market. Procedia Engineering, Volume 182, pp. 306-313.

9. Lukjanov, S. (2020). Piimatootmine kaib juba kolmandat kuud alla omahinna. (Milk production has been below cost for the third month in a row). Postimees. No 6(08). Retrieved: https://leht.postimees.ee/7032990/piimatootmine-kaib-juba-kolmandat-kuud-alla-omahinna. Access 11.03.2021.

10. Piccoli, P., Bianchini J.N., Coser, J., Moreira, V.R. (2020). Short-term Financial Sustainability of Agricultural Cooperatives. Agricultural Finance Review. Vol. ahead-of-print No. ahead-of-print. https://doi.org/10.1108/AFR-06-2020-0097.

11. Pirttila, M., Virolainen, V., Lind, L., Karri, T. (2019). Working Capital Management in the Russian Automotive Industry Supply Chain. International Journal of Production Economics, Volume 221(C): DOI: 10.1016/j.ijpe.2019.08.009.

12. Pollumajanduse, alanduse ja toiduainetoostuse ulevaade 2019. (Overview of Agriculture, Fisheries and the Food Industry 2019) Maaeluministeerium 2020. Retrieved: https://www.agri.ee/sites/default/files/content/ylevaated/ulevaade-pokat-2019-02.pdf. Access 11.03.2021.

13. Statistics Estonia (ESA). EM009. Retrieved: www.stat.ee. Access: 01.03.2021.

14. Uhise pollumajanduspoliitika strateegiakava 2021-2027. (Common Agricultural Policy Strategic Plan 20212027). Pollumajandustootjate sissetulekute ja riskijuhtimise toogrupi I kohtumise memo 30.12.2019. Retrieved: https://www.agri.ee/sites/default/files/content/arengukavad/upp-2021/upp-2021-tg-ptsr-2019-1218-memo.pdf. Access: 11.03.2021. 